\title{
A Mechanism for Dispute Resolution in the Iranian Construction Industry
}

\author{
Abdollah Saeb ${ }^{1,2},{ }^{*}$ Mohd Suhaimi Mohd Danuri², Othman Mohamed² \\ and Norhanim Zakaria²
}

First submission: 23 January 2020; Accepted: 7 September 2020; Published: 30 July 2021

To cite this article: Abdollah Saeb, Mohd Suhaimi Mohd Danuri, Othman Mohamed and Norhanim Zakaria (2021). A mechanism for dispute resolution in the Iranian construction industry. Journal of Construction in Developing Countries, 26(1): 205-226. https://doi.org/10.21315/jcdc2021.26.1.10.

To link to this article: https://doi.org/10.21315/jcdc2021.26.1.10

\begin{abstract}
If disputes are not resolved promptly, they tend to become prolonged and escalated, creating a more complicated and less manageable scenario. Therefore, in this study, we formulated a mechanism for dispute resolution in the Iranian construction industry based on alternative dispute resolution methods. The formulated mechanism could aid disputing parties in the construction industry to settle their disputes more effectively and enhance dispute resolution methods in construction standard forms. To achieve this goal, we collected qualitative data using semi-structured interviews with 30 experts who were selected via purposive sampling method. We used MAXQDA software to manage and organise complete interview transcripts and facilitate the qualitative data analysis process. The proposed mechanism and guidance were finally validated using the survey questionnaire. Negotiation has equal potential for dispute resolution with different sources, and it is recommended as the first step in dispute resolution with any source. According to the results, we recommend a three-step resolution mechanism as follows: negotiation, a method based on sources of disputes and a hybrid method of adjudication and arbitration (Adj-Arb), as the appropriate mechanism for dispute resolution in the Iranian construction industry. Replacing arbitration with Adj-Arb in construction standard forms will have satisfactory results in resolving construction disputes and reply to growing criticism that arbitration is becoming more like litigation.
\end{abstract}

Keywords: Construction management, Iranian construction industry, Dispute resolution, ADR

\section{INTRODUCTION}

Construction projects are highly complex, where multiple parties are involved, which leads to frequent serious disputes (Lee et al., 2017). A significant amount of time and money spent by the disputing parties in litigation (LTSF [Litigation Trends Survey Findings], 2013; Cheung and Yiu, 2006) have led to the emergence of other dispute resolution methods (Mohd Danuri et al., 2015; Glasner, 2000; Treacy, 1995), which is called alternative dispute resolution (ADR) methods (Harmon, 2003). ADR is a term used for all those methods of dispute avoidance and resolution methods other than judicial determination. Nowadays, ADR methods are used widely in order to resolve disputes more efficiently, confidentially and at lower cost than that of litigation. Despite today ADR methods are used widely in order to resolve disputes more efficiently, increasing number of disputes and costs

\footnotetext{
'Fanavaran Jeghato Co., Miandoab, IRAN

²Department of Quantity Surveying, Centre for Building, Construction and Tropical Architecture (BuCTA), Faculty of Built Environment, University of Malaya, Kuala Lumpur, MALAYSIA

*Corresponding author: msuhaimi@um.edu.my
} 
of resolving disputes indicate the need for further research in this area and to innovate new mechanism. Saeb (2018) suggests that in order to resolve disputes, one has to select ADR methods based on the source of disputes so that a resolution takes place quickly, cheaply and effectively.

Contractual issues are significant source of disputes in many projects (Hartman and Snelgrove, 1996; Jahren and Dammeier, 1990). Omoto, Kobayashi and Onishi (2002) concluded that most contractual disputes in construction industry stem from discord over interpretations. Kumaraswamy and Yogeswaran (1998) also indicated that sources of construction disputes are mainly related to contractual matters. Standard contracts provide enough common ground for contractual definitions, clarifications in construction operations and specific project requirements. Contractual knowledge is shared in standard contracts (Shin, 2000). Various standard contracts are used in the construction industry throughout the world. The most famous among them are those used by the International Federation of Consulting Engineers (FIDIC, for Fédération Internationale Des Ingénieurs-Conseils) and American Institute of Architects (AIAs). The Dispute Adjudication Board and arbitration have been introduced by the FIDIC (Menassa, 2009; Peña-Mora and Tamaki, 2001). The AIA utilises the following methods: the architect's decision, mediation and arbitration (Demkin, 2001). The construction standard forms of contracts are proposed ladder methods for resolving disputes at different levels of escalation. The ladder process uses a range of ADR techniques sequentially. They are from non-binding to binding methods. A notable point is that the sequential use of different ADR methods can destroy the originally designed positive effects, especially with regards to time and cost (Saeb et al., 2020; Cheung, Suen and Lam, 2002). Moreover, some countries use their own unique form. The Iranian government's general conditions of contracts (GCC) provides for three dispute resolution methods: submitting an inquiry to the state's MPO (Management and Planning Organization), an expert decision and referring a dispute to the Technical Supreme Council for arbitration. However, these methods are impractical and ineffective (Saeb, 2012; Herisi, 2011 ). Therefore, shortcomings of the GCC in resolving disputes have led contractors to refer to litigation (Herisi, 2011).

The widespread use of standard contract forms and the destructive effects of inappropriate methods to resolve disputes, clearly highlights the importance of research in this area, enhancement standard form contract and creating innovation mechanism. Therefore, by improving and developing dispute resolution methods pertaining to the standard form contract, a significant number of construction disputes could be resolved quickly. This research formulates a mechanism for dispute resolution in the Iranian construction industry based on ADR methods for enhancement of the Iranian standard form contract which could help to solve problems within the Iranian context. The results of this study should contribute to the development of knowledge in this field. We propose negotiating, selecting dispute resolution methods based on source of disputes and a hybrid method of adjudication and arbitration (Adj-Arb) as a final solution, which can be replaced with arbitration in standard contracts and respond to criticisms of arbitration. 


\section{ADR}

Figure 1 shows how dispute avoidance and resolution are classified in the construction industry and Figure 2 shows common construction dispute resolution methods under ADR.

\begin{tabular}{|c|c|c|c|c|}
\hline \multirow{8}{*}{$\begin{array}{l}\text { Dispute } \\
\text { Avoidance and } \\
\text { Dispute Resolution } \\
\text { Methods }\end{array}$} & \multirow{7}{*}{ ADR } & \multicolumn{2}{|c|}{$\begin{array}{l}\text { Conflict management } \\
\text { (dispute avoidance) }\end{array}$} & Prevention techniques \\
\hline & & \multicolumn{3}{|c|}{ Negotiation } \\
\hline & & \multirow{5}{*}{$\begin{array}{l}\text { Dispute } \\
\text { resolution } \\
\text { under ADR } \\
\text { (Third party } \\
\text { techniques) }\end{array}$} & \multirow{2}{*}{ Non-binding } & Facilitative methods \\
\hline & & & & Advisory methods \\
\hline & & & Binding & $\begin{array}{l}\text { Determinative } \\
\text { methods }\end{array}$ \\
\hline & & & $\begin{array}{l}\text { Non-binding or } \\
\text { Binding }\end{array}$ & Combined methods \\
\hline & & & $\begin{array}{l}\text { From non-binding } \\
\text { to binding }\end{array}$ & Ladder processes \\
\hline & \multicolumn{2}{|c|}{ Litigation } & \multicolumn{2}{|c|}{ Binding } \\
\hline
\end{tabular}

Figure 1. Dispute Avoidance and Resolution Methods Source: Saeb (2019)

ADR

Dispute resolution (Third party techniques)

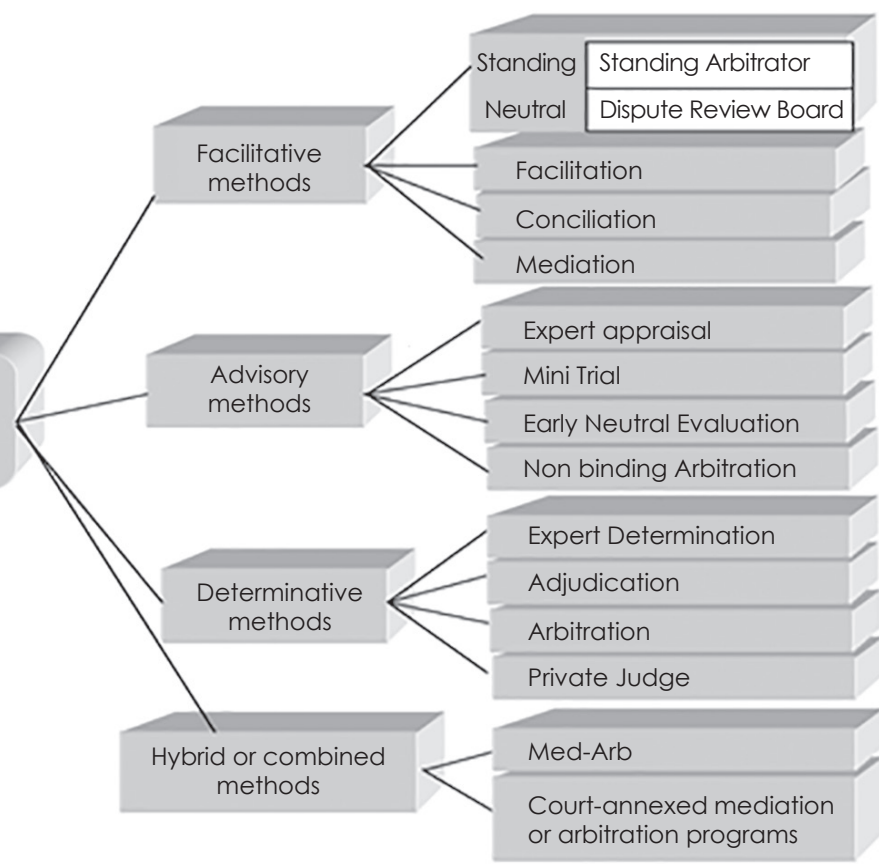

Figure 2. ADR Methods in Construction Industry Source: Saeb et al. (2018a) 


\section{Negotiation}

Negotiation simply involves disputants bargaining to resolve a dispute. In a broad sense, virtually all forms of ADR are based on some form of negotiation. It is the most important tool available for managing and resolving disputes in construction projects, because it offers parties the flexibility of utilising discussion tools to convert the disputable conflicts into mutually advantageous agreements (Pena-Mora, Sosa and McCone, 2003). The importance of this method lies in the fact that parties have total control over the outcome of the negotiations. However, they should be willing to participate in competitive free negotiations that focus on finding "win-win" solutions rather than "zero-win" objectives.

\section{Step Negotiation}

This kind of negotiation provides the project participants with a method to start negotiation at the lowest possible organisational level. If the issue is not resolved at that level within a pre-specified time limit, then it is endorsed to a higher level in the management until a resolution is achieved (Pena-Mora, Sosa and McCone, 2003).

\section{Expert Determination}

Expert determination is a method "in which the parties to a dispute present arguments and evidence to a dispute resolution practitioner, who is chosen on the basis of their specialist qualification or experience in the subject matter of the dispute (the expert) and who makes a determination" (Sourdin, 2006). The process by which the expert structures the investigation is primarily governed by the expert and usually conditional on the type of dispute in question. The expert may meet privately with each party, together with both parties or determine the merits of the dispute purely through assessment of facts and statements. This process is normally binding but is dependent on the contractual situation of the parties (Gad, 2012).

\section{Adjudication}

The Housing Grants, Construction and Regeneration Act 1996 provides that a party to a construction contract has a right, at any time, to refer any dispute under the contract for adjudication (Ndekugri and Russell, 2005) The term "adjudication" is generally understood in the construction industry as a method of resolving disputes whereby the parties to a construction contract, as part of their contract, agree that a neutral third party, referred to as the "adjudicator", will decide specific types of disputes in connection with their contract (McGaw, 1995). The provision of United Kingdom (UK) adjudication includes the following four aspects:

1. Time: It allows for 7 days for the appointment of the adjudicator. The decision must be given within 28 days of the referral unless the parties agree to extend.

2. Procedure: It is for the adjudicator to take the initiative in ascertaining the facts and the law. In other words, it was intended to be an inquisitorial rather than an adversarial system. 
3. Binding nature of the decision: The decision is binding, unless and until determined by litigation, arbitration or agreement. In other words the decision has temporary finality.

4. Immunity of the adjudicator: Under the contract, the adjudicator is given immunity from suit, other than in cases of bad faith (Kennedy, 2008).

Adjudication is a dispute resolution process in which a neutral adjudicator decides a contractual dispute between the parties within a predetermined time limit, which is usually quite short. The adjudicator's decision is binding on the parties as a matter of contract. However, it is not usually final at the time it is given but may become so in certain circumstances if the contract so provides (Ross, n.d.). Either party may appeal the adjudicator's decision to court or arbitration, or indeed settle the dispute by mediation (Brooker and Lavers, 1997).

The time limit for the decision making is the distinguishing characteristic of adjudication. As there are understandable limits to the quantity of information which an adjudicator can assimilate within any given time period, it calls for focused submissions by the parties and considerable discipline by the adjudicator. It is often described as rough justice, but it depends on the time limit allowed, the quality of the submissions and the complexity of the issues the adjudicator is asked to determine. This matter is largely in the parties' hands. The adjudicator does what he can with what he is given within the available time, and is often given inquisitorial powers to facilitate proactively.

Adjudication has many of the characteristics of arbitration, except that the adjudicator is required to make his decision within a predetermined, but usually extendable, time limit. The adjudicator's decision is usually binding but not final, which means, it is enforceable even if a dissatisfied party subsequently refers the dispute afresh to a more final form of dispute resolution. The irony of this is that, assuming that the courts in the relevant jurisdiction are as willing to enforce adjudicators' decisions as they are in the UK, then the winner in adjudication generally gets to hold the disputed funds during any subsequent dispute resolution procedure.

Of the determinative procedures, with the possible exception of expert determination, adjudication by virtue of its speed will usually prove the most economic. The UK's enthusiasm for the construction adjudication has spread to Australia, New Zealand, Hong Kong, Singapore and Texas. The Construction Industry Payment and Adjudication Act of Malaysia received royal assent and became law on 18th June 2012 (Gould, 2012). Therefore, it is expected that adjudication will spread throughout the world.

\section{Arbitration}

Worldwide, arbitration is one of the most commonly used ADR techniques because knowledgeable experts in the field of construction disputes typically issue the decisions. These decisions are impartial, final and binding on the parties (PenaMora, Sosa and McCone, 2003).

Typically, the proceedings are administered by an organisation, such as the American Arbitration Association (AAA), which will have specific rules for the process (Nelson, 2003). However, parties may set up their own rules in the contract 
as long as both parties agree with those rules. Final decisions of the arbiter are final, binding and generally not reviewable by the court system (Stipanowich, 1987).

When the construction industry became disenchanted with the time and costs of litigating disputes, it turned to arbitration (Steen and MacPherson, 2000; CroninHarris, 1995). Arbitration is a contractual dispute resolution mechanism. Arbitration clauses have been used in standard agreements since 1871 (ASFE [Associated Soil and Foundation Engineers], 1988) and for many years, they were used as the only alternative to litigation (Stipanowich, 1997). The clauses have been incorporated into standard contracts published by the AIAs since 1915 (Treacy, 1995) and by the Associated General Contractors (DiDonato, 1993). They are widely used in the construction industry today for both private and public contracts.

Initially, arbitration was thought to be an inexpensive, efficient, prompt, private and informal process, with decisions made by experienced industry professionals (Braun, 1998). Arbitration, like litigation, is a confrontational and adversarial process with a win-lose premise (ASFE, 1988). Both can be expensive and lengthy (Gillie et al., 1991) and both involve a significant delay from the time the dispute arises until the presentation of facts to others for a binding decision (Shadbolt, 1999).

Thus, arbitration has recently received sharp criticism from academicians and practitioners alike. Anecdotes about the process, the arbitrators and the decisions have shown that arbitration proceedings are becoming more and more like litigation (Erdis and Ozdemir, 2013; Groton, Blumenfeld and Ratterman, 2005; Trantina, 2003). Despite the growing criticism, arbitration remains the preferred ADR (Kangari, 1995). According to Gad and Shane (2017), arbitration is most recommended in all project conditions except in projects with high trust, where negotiation is recommended. Arbitration also remains a standard part of the AIA and Associated General Contractors of America (AGC) documents.

\section{Arbitration in the Civil Procedure Code of Iran}

The Civil Procedure Code deals with the litigation, arbitration and compromise process. All those who have the capacity to raise a dispute may refer to one or more arbitrators according to an agreement, if discussed in the court and at any stage (ICPC [Iranian Civil Procedure Code], 2000).' Dealers may be required, during their deal, to refer any dispute to arbitration and may also select their desired arbitrator(s) before or after the dispute or may compromise through a separate contract (ICPC, 2000). ${ }^{2}$

According to Note $\$ 455,{ }^{3}$ in all cases of referral to an arbitrator, both parties may select the arbitrator(s) or may leave that to a third party or court. The length of arbitration can be as long as the parties have agreed on in the contract, but if the parties did not define any period, it would last for three months commencing from the date of reference of the claim to arbitration. The duration may be extended by agreement (ICPC, 2000). ${ }^{4}$

Although it has been over 100 years since arbitration provisions have been passed in Iran, this method has not been developed officially and as it should have been (Yousefzade, 2004). Arbitration is a traditional method in Iran but is uncommon and rare (Dorri, 2014; The World Bank, 2011; Darvishi, 2005; Katozeyan, 2003; Ranjbar, 2003). 


\section{CONSTRUCTION DISPUTE RESOLUTION UNDER IRANIAN GCC}

Aiming to establish an integrated system to create investment plans and projects, the State Technical and Executive System (TES) was approved by the Board of Ministers in 2006. TES is in charge of the managerial regulations, processes, standards, technical criteria, terms and conditions, procedures and manuals used to design and operate investment plans and projects (MPO, 2006).

The State MPO is responsible for preparing and codifying similar contracts, relevant policies and manuals, monitoring the implementation of construction projects, recognising qualifications and issuing operating licenses for technical and executive agents such as contractors and consultants (President Deputy in Strategic Planning and Control, 2015).

The methods to resolve disputes in construction projects approved by the Board of Ministers in 1998 have been included in Article 53 of the GCC. According to this article, if any dispute arises while performing or interpreting the context of contract between two parties, both parties can ask for an inquiry from the State MPO or refer to Expert Decision to solve the problem rapidly before referring the dispute to arbitration of the Technical Supreme Council (Majlis, 1972). The Technical Supreme Council is one of the councils of the State MPO, consisting of three members, all of whom are appointed by the agreement of the Advisor Minister, Chief of State MPO and Board of Ministers (Majlis, 1972). Figure 3 summarises the GCCs outlined by the Iranian government (Saeb et al., 2020). However, these suggested methods for dispute resolution in the GCC are rather impractical and ineffective (Saeb, 2012; Herisi, 2011).

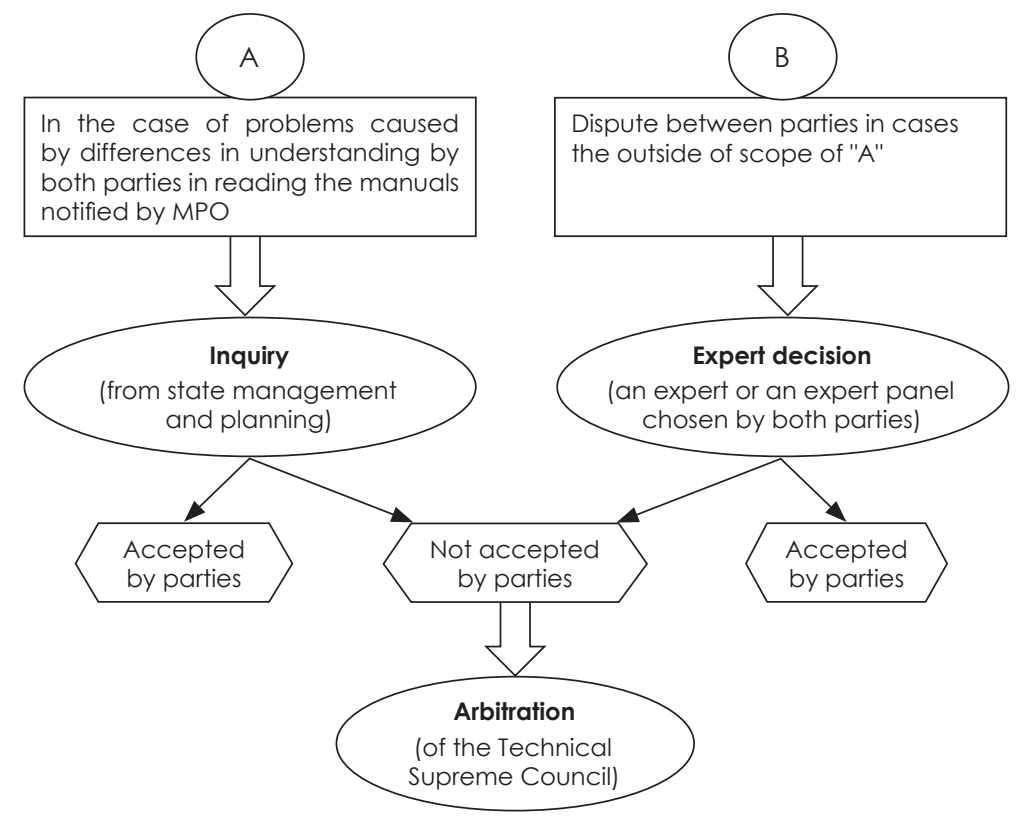

Figure 3. Iranian Government's General Conditions of Contracts Source: Saeb (2019) 
The convey of claims about public properties to be referred to for arbitration must be approved by the Board of Ministers and the Islamic Consultative Assembly must be notified. If the claimant is a foreigner, then the important interior affairs must be approved by the Islamic Consultative Assembly. The important affairs may be defined by the law (Saeb et al., 2020). Arbitration of the Technical Supreme Council is structured in such a way so as to bypass Article 139 of the Iranian Constitution. Arbitration of the Technical Supreme Council is a binding arbitration. However, the arbitration award will be null and unenforceable in the following cases (ICPC, 2000):

1. The award is against principles and rules causing the right.

2. The arbitrator has decided on something different from the subject of arbitration.

3. The arbitrator has decided beyond his/her authorities. In these cases, only some part of the award will be nullified which is beyond the arbitrator's authorities.

4. The arbitration award is issued and announced after the deadline.

5. The arbitration award is against legally accurate records of real estates or of parties in the notary public.

6. Arbitrators are awarded but have not been authorised.

7. The arbitration contract has been invalid.

If the cases mentioned above occur, then both parties may refer to the court submitted to for the claim for arbitration or another competent court to address the claim within 20 days after notification of the arbitration award and ask to nullify the arbitration award. Under these circumstances, the court is required to address the request and nullify the arbitration award. Therefore, arbitration awards will fail to consider the main claim and certainty in the nullification of the order (ICPC, 2000).

\section{METHODOLOGY}

In this study, we formulated a mechanism for dispute resolution in the Iranian construction industry. To achieve this goal, we collected qualitative data through semi-structured interviews with 30 experts involved in five construction disputes in Iran. Parties to the conflicts included contractors, owners, consultants, official experts and lawyers (six interviewers from each group). Table 1 shows the experts' attributes. Selection of different groups from different locations (nationwide), adherence to data collection strategies and linkage of qualitative research to the existing literature and theories in qualitative research increase the validity of this study (Saunders et al., 2011). Involvement with construction conflicts or disputes or special experience in this field was the criterion used to sample individuals from the above groups. For the interviews, a purposive sampling scheme was followed, which enables people to rely on their judgment to select cases that are best suited to their research question(s) and objectives. One such sample with a purpose has been considered in a previous study (Saunders et al., 2011). 
Table 1. Attributes of Interviewees

\begin{tabular}{|c|c|c|c|c|}
\hline $\begin{array}{l}\text { Interviewee } \\
\text { Codes }\end{array}$ & Document Group & $\begin{array}{c}\text { Year of } \\
\text { Experience }\end{array}$ & Degree & Field of Degree \\
\hline El & Lawyer & 8 & Doctorate & Private law \\
\hline E2 & Lawyer & 7 & Master & Private law \\
\hline E3 & Lawyer & 7 & Doctorate & Private law \\
\hline E4 & Lawyer & 8 & Doctorate & Private law \\
\hline E5 & Lawyer & 10 & Master & Penal law \\
\hline E6 & Lawyer & 10 & Master & Private law \\
\hline E7 & Official expert & 30 & Graduate & Civil-water \\
\hline E8 & Official expert & 40 & Master & Construction \\
\hline E9 & Official expert & 20 & Master & Architecture \\
\hline E10 & Official expert & 30 & Graduate & Civil engineering \\
\hline E11 & Official expert & 40 & Master & Construction \\
\hline E12 & Official expert & 20 & Graduate & Civil engineering \\
\hline E13 & Contractor & 30 & Master & Construction \\
\hline E14 & Contractor & 15 & Graduate & Civil engineering \\
\hline E15 & Contractor & 34 & Master & Construction \\
\hline El6 & Contractor & 25 & Master & Foundation \\
\hline E17 & Contractor & 10 & Master & Architecture \\
\hline E18 & Contractor & 20 & Graduate & Civil engineering \\
\hline E19 & Consultant & 12 & Master & Structures \\
\hline E20 & Consultant & 25 & Master & Civil engineering \\
\hline E21 & Consultant & 8 & Doctorate & Construction \\
\hline E22 & Consultant & 14 & Master & Architecture \\
\hline E23 & Consultant & 15 & Master & Earthquake \\
\hline E24 & Consultant & 15 & Graduate & Civil engineering \\
\hline E25 & Owner & 17 & Master & Structures \\
\hline E26 & Owner & 22 & Graduate & Civil engineering \\
\hline E27 & Owner & 15 & Master & Structures \\
\hline E28 & Owner & 15 & Graduate & Civil engineering \\
\hline E29 & Owner & 32 & Graduate & Law \\
\hline E30 & Owner & 20 & Master & $\begin{array}{c}\text { Project } \\
\text { management }\end{array}$ \\
\hline
\end{tabular}


In this study, snowball sampling was also applied. Snowball sampling is a subcategory of the purposive sampling method. It begins with identifying the individuals who meet the criteria for being included in this study. Individuals are asked to recommend similar individuals who meet the same criteria. MAXQDA software (VERBI GmbH, Berlin, Germany) was used to manage and organise complete interview transcripts and facilitate the qualitative data analysis process. Figure 4 shows the steps taken in the qualitative data analysis.

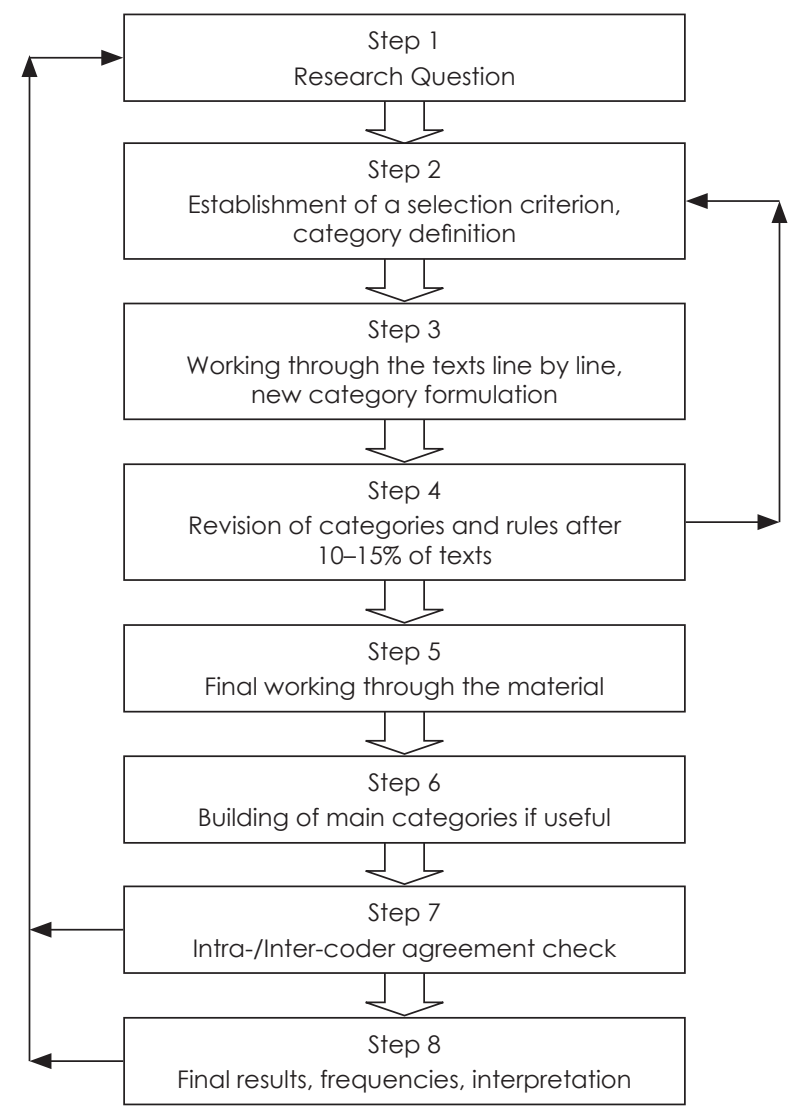

Figure 4. Steps of Data Analysis Source: Mayring (2014)

\section{RESULTS AND DISCUSSION}

Based on the literature review and the research finding, a three-step mechanism was followed for dispute resolution in the Iranian construction industry: negotiation, proving and impel and Adj-Arb. The proposed mechanism and guidance were finally validated using the questionnaire survey. 


\section{Proper Method to Resolve Disputes in Iranian Construction Industry}

Majority of the respondents proposed an independent, organisational and professional arbitration by an arbitration panel made up of two experts and one lawyer as a final solution. However, the characteristics that they defined for the arbitration show their purpose indeed is adjudication then arbitration or a hybrid method of Adj-Arb. This is because they emphasised the time limits and the revisable binding sentences at the head office.

In the following table, the codes, categories and the defined criteria for the recommended method are explained and displayed with some text passages of the expert participant opinions. Table 2 shows the results. This table gives an order to the categories following the frequency of the experts' mention about it.

Table 2. Coding Defining Criteria for the Recommended Method for Resolving Construction Disputes

\begin{tabular}{lc}
\hline Codes Ranked by Frequencies & Number of Experts \\
\hline C1: An independent, organisational and professional arbitration & 21 \\
C2: The sentence released through a 3-member panel of which & 16 \\
two are experts and one is a lawyer & 15 \\
C3: The sentence should be binding but can be revised at the & \\
head office & 8 \\
C4: All stages of dispute resolution should have appropriate & \\
time-scheduling & 7 \\
C5: It should have branches in all states of the country &
\end{tabular}

\section{C1: An independent, organisational and professional arbitration}

"The best way is to establish a specialised and independent arbitration body." (E1)

"I suggest a well-regulated organised and specialised arbitration on a timely basis." (E2)

"A professional and structured organisation with a special panel consisting of technical and legal experts to handle disputes." (E20)

"An organisation led by a specialised arbitration panel of technical and legal experts." (E22)

"An arbitration panel with the required expertise and organisational arrangement." (E23)

"A specialised organisation wherein a panel of experts undertake the arbitration process." (E30) 


\section{C2: The sentence released through a 3-member panel of which 2 are experts and 1 is a lawyer}

"...to be governed by a three-member panel consisting of an ex-contractor expert, an ex-owner expert and a lawyer." (E1)

"I recommend a three-member panel of two experts and a lawyer for organisational arbitration." (E10)

"Professional and organised Arbitration by an arbitration panel made up of two experts and one lawyer."(E11)

"Arbitration by a three-member board made up of two experts and one lawyer." (E12)

\section{C3: The sentence should be binding but can be revised at the head office}

"Arbitration with binding decisions... binding but revisable." (E3)

"The panel should then follow a well-defined timing and be provided with the right to make binding yet revisable decisions." (E10)

"Professional and organised arbitration... it must have branches in different provinces, with its decisions revisable at the head office." (E11)

"An organisation led by a specialised arbitration panel of technical and legal experts, with decisions made preliminary in provincial branches and finalised at the head office." (E22)

"Arbitration by a specialised and independent arbitral panel making binding y et revisable decision(s)." (E29)

"The organisation must establish branches in different provinces with their decisions being revisable at the head office." (E30)

\section{C4: All stages of dispute resolution should have appropriate time-scheduling}

"...with binding decisions to be made on exact schedules." (E3)

"I suggest binding arbitration made on exact schedules." (E4)

"Arbitration... at exact timing." (E12)

"I recommend organised and professional arbitration to be made on exact schedules." (E19)

"All processes should be defined clearly within a limited time window." (E20) 


\section{C5: It should have branches in all states of the country.}

"This independent agency should have branches in all provinces of the country." (E1)

"It must have branches in all provinces, with its decisions being binding yet revisable." (E7)

"The arbitration body must establish branches in all provinces, with the decisions being revisable at the head office." (E17)

\section{The proposed mechanism for dispute resolution in Iranian construction}

According to the Oxford dictionary, a mechanism means a natural or established process by which something takes place or is brought about. The term "mechanism" is quite common in social since and has a long history, but it is nearly always used in a casual everyday sense (Hedstrom and Swedberg, 1998). A mechanism is an institution, procedure, or game for determining outcomes (Maskin, 2008). The mechanism converts an input to an output and in a dispute resolution mechanism, disputes (input) end with an agreement or a definite sentence (output). Mechanism design is a methodology which employs structured procedures to give the parties incentives to reach agreement and mechanisms constitute algorithmic altering rules that reduce if not eliminate inefficient transaction costs (Brams and Mitts, 2012). It is the art of designing the rules of the mechanism so that a desirable outcome is reached despite the fact that each agent acts in his own selfinterest (Sandholm, 2003). A dispute resolution mechanism is the use of structured procedures to reduce transaction costs and social externalities (Brams and Mitts, 2012). According to Friedman (Friedman, 1969), a legal viable mechanism normally consists of two main elements: structural and substantive. Structural elements are the forms and process and substantive elements are the laws such as the rules and doctrine (Mohd Danuri et al., 2016) applied to formulating a viable legal system in the Malaysian construction industry. Figure 5 shows formulating a viable dispute resolution mechanism for the Iranian construction industry. In the following extraction, the proposed mechanism from the research results and the mechanism rules conformity with the current rules and laws are explained.

Process Negotiation: It is a method based on the sources of disputes and AdjArb. The importance of negotiation to solving construction disputes in literature has been previously emphasised by many researchers. For example, according to Saeb (2019), negotiation to resolve disputes with different sources in the construction industry has a high potential. The author also suggested selecting dispute resolution methods based on the source of dispute.

In this study, majority of the research participants proposed arbitration as final resolution for construction disputes. However, their defined characteristics for the arbitration show their purpose, which is a hybrid method of Adj-Arb. This is because they emphasised time limits and the revisable binding sentences at the head office.

Form: In this mechanism, referring to the next step does not require the passing and documenting of the previous step. For example, each party may, without using dispute resolution methods based on the sources of the disputes (Step 2), refer to Adj-Arb. This is because using a range of ADR techniques sequentially may destroy 
the original design that achieves positive effects, especially with regards to time and cost (Saeb et al., 2018a; 2018b). The remarkable thing that can be deduced from the three-step mechanism is that respondents offered three different levels to resolving disputes: convincing level (negotiation), proving and impel level (shortcut methods) and forcing level (Adj-Arb).

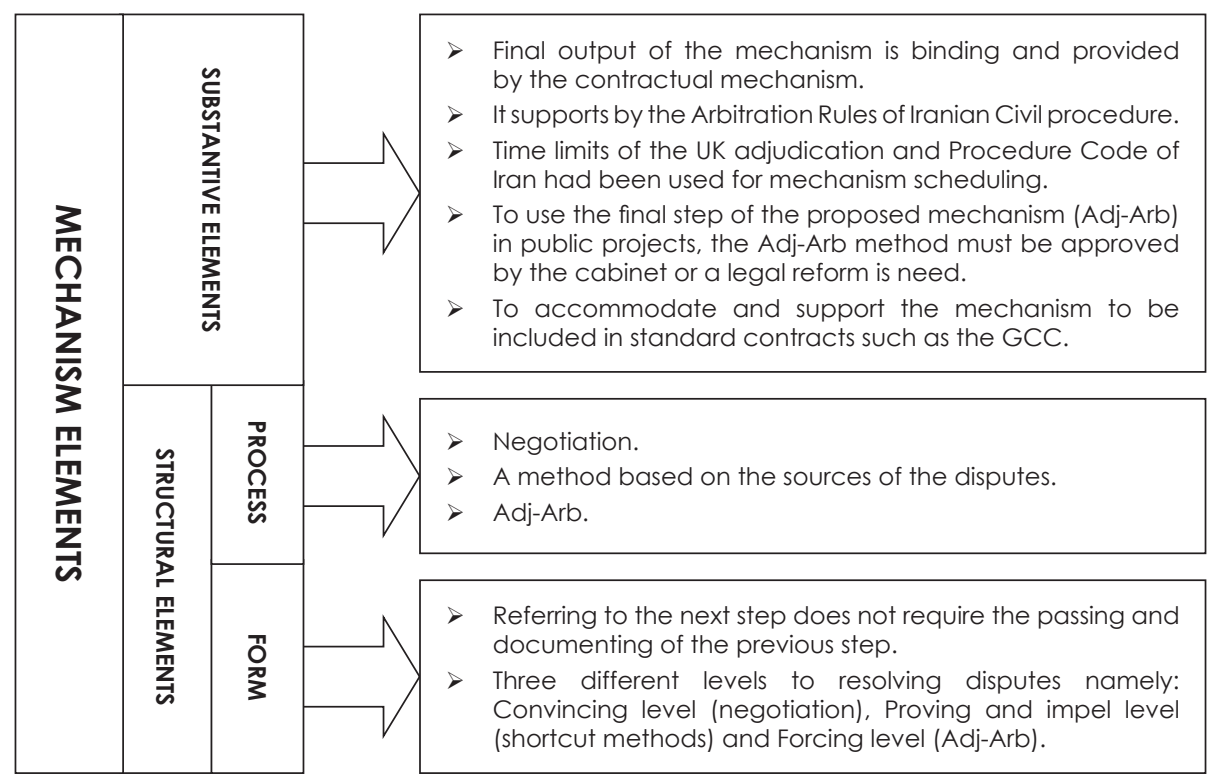

Figure 5. Formulating a Viable Dispute Resolution Mechanism for the Iranian Construction Industry

Substantive Elements: For dispute resolution, Steps 1 and 2 are optional and may be employed by mutual agreement but referring to Step 3 is compulsory, which is provided by the contractual mechanism. The main and final part of this mechanism is the Adj-Arb method, which is a hybrid binding method. Binding methods for resolving construction disputes were emphasised by the participants of this research. Adj-Arb supports by the Arbitration Rules of Iranian Civil Procedure. Arbitration is the most well-known method in the Iran of all other ADR methods (Hartman and Snelgrove, 1996).

Time limits of the UK adjudication and Procedure Code of Iran had been used for mechanism scheduling as follows. Designed scheduling was confirmed in the validation phase.

1. Time of provincial adjudication: Allows 7 days for the appointment of the adjudicator(s). The decision must be given within 28 days of the referral unless the parties agree to extend.

2. Appeals and adjudication reviews made by the provincial adjudicator should be submitted within 20 days. 
3. Time of arbitration: Three months is required from the date of the submission of appeals to the arbitration date. The duration may be extended by the agreement.

4. According to the constitution of Iran, every arbitration mechanism to resolve disputes in public projects must be approved by the cabinet (Saeb, 2019). Therefore, to use the final step of the proposed mechanism (Adj-Arb) in public projects, the Adj-Arb method must be approved by the cabinet, or a legal reform is needed to accommodate and support the mechanism to be included in standard contracts such as the GCC.

Figure 6 shows the proposed mechanism. The following steps explain the mechanism.

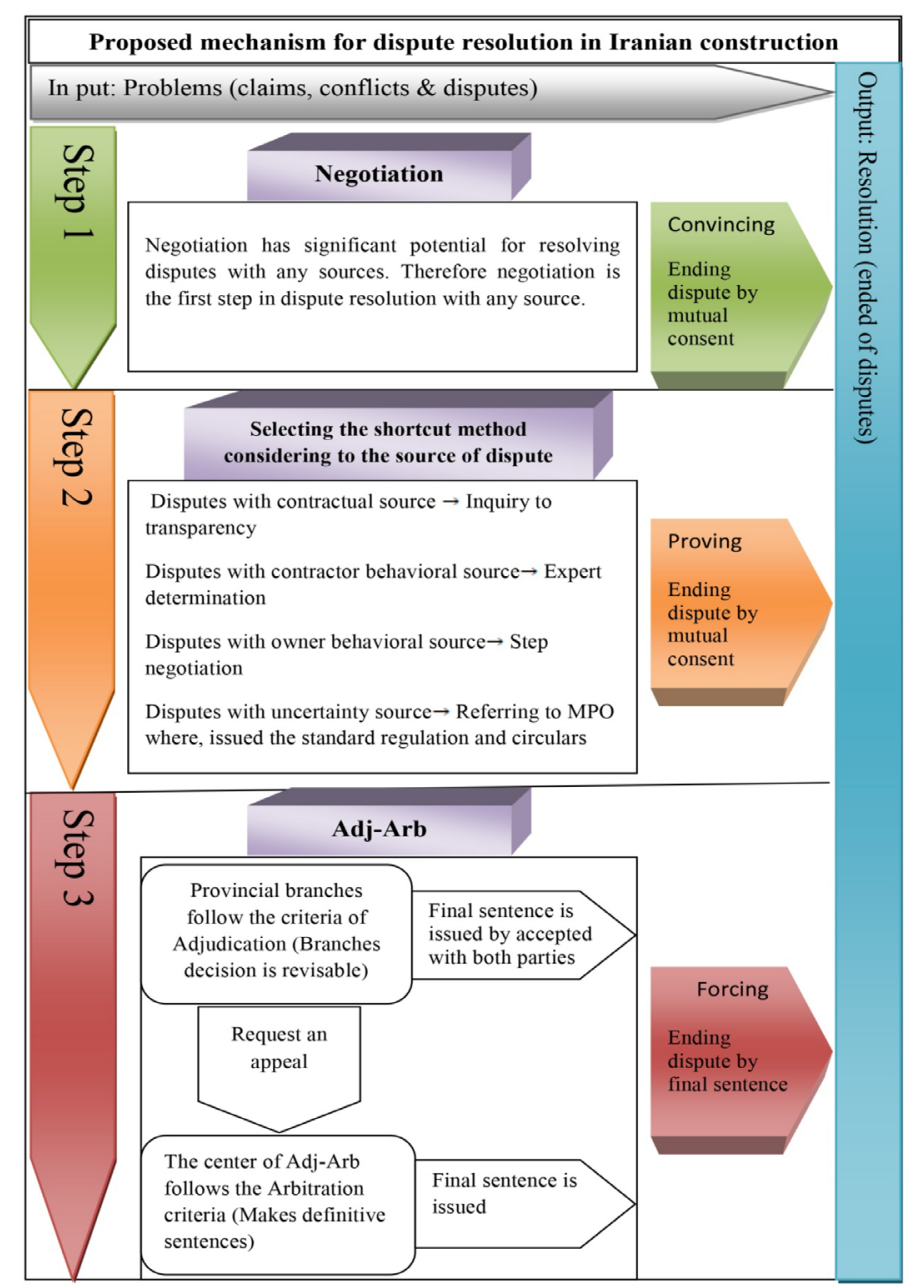

Figure 6. Proposed Mechanism for Dispute Resolution in Iranian Construction 
Step 1 is negotiation (convincing level; mutually advantageous agreements): Negotiation has equal potential for dispute resolution with different sources. It has potential for resolving any construction dispute as high level or average level (Saeb, 2019). Therefore, negotiation is the first step in dispute resolution with any source.

Step 2 is selecting the shortcut method by considering the source of the dispute (proving and impel level; one side impel [push] the other side to accept the demands by referring to third party advice):

1. To resolve disputes with contractual sources, inquiring for transparency (as recommended by Saeb [2019]). Inquiring from the authority who provided the contract documents for transparency concerning issues disputed is also recommended. In the first contract, parties attempt to show transparency and dispel the misunderstanding.

2. To resolve disputes with the contractor's behaviour as a disputed source: Parties can use expert determination before referring to arbitration if they are looking for faster options.

3. To resolve disputes with the owner's behaviour as a disputed source: Step "Negotiation" is advisable for resolving disputes when the source of the dispute is the owner's performance.

4. To resolve disputes with uncertain sources: As an initial solution, most respondents suggested referring to the organisation which issued the standard regulations and circulars to the owners and contractors. This organisation can solve the problem by issuing appropriate circulars (in Iran, it is the Management and Planning Organization) (Saeb, 2019).

Step 3 is the Adj-Arb (forcing level; the final and binding decision): An independent, organisational and professional arbitration by an arbitration panel made up of two experts and a lawyer as the final solution. However, the characteristics that they defined for the arbitration show their purpose indeed is adjudication then arbitration or a hybrid method of adjudication then arbitration (Adj-Arb). This is because they emphasised time limits and the revisable binding sentences at the head office.

Adj-Arb is a hybrid method of adjudication and arbitration. It is professional in construction disputes and has branches in all provinces. Disputes in each province are handled by Adj-Arb branches in the same province. Provincial branches follow of the criteria of adjudication. Hence, investigation and decision making should be done in a time limit. The decision of the branch is also revisable in Adj-Arb. The centre of Adj-Arb follows the arbitration criteria and makes a definitive sentence (refer to previous section).

\section{VALIDATION OF THE MECHANISM}

The proposed mechanism and guidance were finally validated using the questionnaire survey. A total of 15 respondents were selected from various types of construction disputes involved groups such as contractors, owners, consultants, official expert and lawyers. A combination of groups for feedback and validation was to ensure the concept of accuracy and reliability which appear to underpin 
the validity and reliability of the research finding (Winter, 2000). The questionnaires were sent by email and were followed-up by the telephone. The respondents were selected by the process of interview (three respondents from each group). This was to ensure that they already had an understanding of the research study and to achieve continuity and validity of the information about the dispute resolution mechanism. Participants were selected to confirm that they had been provided with accurate information and detailed data for the mechanism. They showed their enthusiasm in research topic (Mohamed, 2014). Creswell (2009) also suggested that to determine the authenticity of the findings, specific items should be returned to the participants (member checking).

The mechanism of validation was measured through the questionnaire based on five variables namely, "Reasonable structure", "Suitable rules", "Capability of acceptance in the construction industry", "Appropriateness for the construction industry" and "Usefulness of the mechanism", with an interval measurement from 1 to 5 ( 1 = Very useful; 2 = Useful; 3 = No opinion; 4 = Less useful; 5 = Not useful at all). Table 3 shows the mean score of each variable. The "Usefulness of the mechanism" had a mean score of 1.13, "Reasonable structure of mechanism" had a mean score of 1.2, "Suitable rules" and "Appropriateness for the construction industry" had a mean score of 1.27 and "Capability of acceptance in the construction industry" had a mean score of 1.47 .

Table 3. Descriptive Statistics for Validation

\begin{tabular}{lccccc}
\hline & N & Minimum & Maximum & Mean & Std. Deviation \\
\hline Reasonable structure & 15 & 1.00 & 2.00 & 1.2000 & 0.41404 \\
Suitable rules & 15 & 1.00 & 2.00 & 1.2667 & 0.45774 \\
Capability of & 15 & 1.00 & 2.00 & 1.4667 & 0.51640 \\
acceptance & 15 & 1.00 & 2.00 & 1.2667 & 0.45774 \\
Appropriateness & 15 & 1.00 & 2.00 & 1.1333 & 0.35187 \\
Usefulness & 15 & & & & \\
Valid N (listwise) & & & & & \\
\hline
\end{tabular}

\section{CONCLUSION}

Despite the fact that there are some codified laws in arbitration and compromise within the Iranian legal framework, they are limited in use. Therefore, the litigation process remains as the main method for resolving disputes though it has severe disadvantages including damages to relationships, high cost and time-consuming. Majority of the respondents proposed an independent, organisational and professional arbitration by an arbitration panel made up of two experts and a lawyer as a final solution. However, the characteristics that they defined for the arbitration show their purpose indeed is adjudication then arbitration or a hybrid method of Adj-Arb.

Despite the growing criticism, arbitration is becoming more like litigation. Arbitration is still the preferred ADR method which is now a standard part of general construction forms. Replacing arbitration with Adj-Arb will have satisfactory results 
in resolving construction disputes. Our results showed a three-step mechanism including: negotiation, a method based on the sources of the disputes and Adj-Arb, as the appropriate mechanism for dispute resolution of the Iranian construction industry. The results of this study should enhance the dispute resolution methods in the construction industries' standard forms which are widely used around the world.

\section{NOTES}

1. Article 454 of Iranian Civil Procedure Code in General and Revolutionary Courts.

2. Article 455 of Iranian Civil Procedure Code in General and Revolutionary Courts.

3. Note of Article 455 of Iranian Civil Procedure Code in General and Revolutionary Courts.

4. Article 484 of Iranian Civil Procedure Code in General and Revolutionary Courts.

5. Articles 489 and 490 of Iranian Civil Procedure Code in General and Revolutionary Courts

\section{REFERENCES}

ASFE (Associated Soil and Foundation Engineers) (1988). Alternative Dispute Resolution for the Construction Industry. Silver Springs, MD: Association of Engineering Firms Practicing in the Geosciences.

Brams, S. J. and Mitts, J. R. (2012). Law and mechanism design: Procedures to induce honest bargaining. NYU Annual Survey of American Law, 68(4): 729790. https://doi.org/10.2139/ssrn.2161045.

Braun, J. (1998). Arbitration: Promises made, promises broken. Public Management, 80: 9-11.

Brooker, P. and Lavers, A. (1997). Perceptions of alternative dispute resolution as constraints upon its use in the UK construction industry. Construction Management and Economics Journal, 15(6): 519-526. https://doi.org/10 .1080/014461997372728.

Cheung, S.O. and Yiu, T.W. (2006). Are construction disputes inevitable? IEEE Transactions on Engineering Management, 53(3): 456-470. https://doi.org/ 10.1109/tem.2006.877445.

Cheung, S.O., Suen, H.C. and Lam, T.I. (2002). Fundamentals of alternative dispute resolution processes in construction. Journal of Construction Engineering and Management, 128(5): 409-417. https://doi.org/10.1061/(asce)07339364(2002) 128:5(409).

Creswell, J. (2009). Research Design: Qualitative, Quantitative, and Mixed Methods Approaches. Thousand Oaks, CA: SAGE Publications, Inc.

Cronin-Harris, C. (1995). Mainstreaming: Systematizing corporate use of ADR. Albany Law Review, 59: 847.

Darvishi, H.Y. (2005). Shyve hay jâyghzin yâ gher ghzayi [Alternative or non-judicial methods for dispute settlement]. Gazavat Magazine, 32: 34-39.

Demkin, J.A. (2001). The Architect's Handbook of Professional Practice. Vol. 1. Hoboken, NJ: John Wiley \& Sons.

DiDonato, L. (1993). Alternate Methods to Resolve Contract Disputes: Approaches to Effective Prevention. West Virginia: American Association of Cost Engineers. 
Dorri, M.H. (2014). Vzeyet Keshvar ha dr Khwsowse Etaleya Dâdrasi [Country situations on the prolongation of the proceedings]. Comparative studies report of Strategic Research Center of President Deputy. Tehran: Strategic Research Center of President Deputy.

Erdis, E. and Ozdemir, S.A. (2013). Analysis of technical specification-based disputes in construction industry. KSCE Journal of Civil Engineering, 17(7): 1541-1550. https://doi.org/10.1007/s12205-013-0016-7.

Friedman, L.M. (1969). Legal culture and social development. Law and Society Review, 4(1): 29-44. https://doi.org/10.2307/3052760.

Gad, G.M. (2012). Effect of culture, risk, and trust on the selection of dispute resolution methods in international construction contracts. PhD diss. lowa State University. https://doi.org/10.31274/etd-180810-674.

Gad, G.M. and Shane, J.S. (2017). Culture-risk-trust model for dispute-resolution method selection in international construction contracts. Journal of Legal Affairs and Dispute Resolution in Engineering and Construction, 9(4): 04517020. https://doi.org/10.1061/(asce)la.1943-4170.0000242.

Gillie, P., Goetz, P., Muller, F. and Feinberg, K.R. (1991). Using mediation to resolve construction disputes. In R.F. Cushman, G.C. Hedemann and A.S. Tucke (eds.), Alternative Dispute Resolution in the Construction Industry. Chichester, England: Wiley Law, 153-210.

Glasner, K. (2000). Contract disputes: The role of ADR. Dispute Resolution Journal, 55(3): 50 .

Gould, N. (2012). Adjudication: Malaysia. Available at: http://www.fenwickelliott. com.

Groton, J.P., Blumenfeld, A. and Ratterman, D. (2005). How to keep your project out of litigation, arbitration, and even mediation. Paper presented at the Cll Annual Conference "Leadership of Tomorrow: Bridging the Gap". Grapevine, Texas, 20 July.

Harmon, K.M. (2003). Resolution of construction disputes: A review of current methodologies. Leadership and Management in Engineering, 3(4): 187-201. https://doi.org/10.1061/(asce)1532-6748(2003)3:4(187).

Hartman, F. and Snelgrove, P. (1996). Risk allocation in lump-sum contracts: Concept of latent dispute. Journal of Construction Engineering and Management, 122(3): 291-296. https://doi.org/10.1061/(asce)0733-9364(1996)122:3(291)

Hedstrom, P. and Swedberg, R. (eds.) (1998). Social mechanisms: An introductory essay. In Social Mechanisms: An Analytical Approach to Social Theory. Cambridge, UK: Cambridge University Press, 1-31. https://doi.org/10.1017/ cbo9780511663901.001

Herisi, I.I. (2011). Hghoghe Mohandesi [Engineering law, note of the contract]. Tehran: Enteshârâte Dâdghostar.

ICPC (Iranian Civil Procedure Code) (2000). Ghânon Aein Dâdrasi Dâdegh hy Emomy $\vee$ Enghlâb dr Emore Madani Iran Act [Iranian civil procedure code in general and revolutionary courts act]. Tehran: ICPC.

Jahren, C.T. and Dammeier, B.F. (1990). Investigation into construction disputes. Journal of Management in Engineering, 6(1): 39-46. https://doi.org/10.1061/ (asce)9742-597x(1990)6:1(39).

Kangari, R. (1995). Construction documentation in arbitration. Journal of Construction Engineering and Management, 121(2): 201-208. https://doi.org/10.1061/ (asce)0733-9364(1995)121:2(201). 
Katozeyan, N. (2003). Eøtebâr Amreh Gazâvat Shodeh dr Dâvi Madani [Validity of the judgment in civil affairs]. Tehran: Enteshârâte Meyzan.

Kennedy, P. (2008). Evolution of statutory adjudication as a form of dispute resolution in the UK construction industry. Journal of Professional Issues in Engineering Education and Practice, 134(2): 214-219. https://doi.org/10 $.1061 /$ (asce) 1052-3928(2008)134:2(214).

Kumaraswamy, M.M. and Yogeswaran, K. (1998). Significant sources of construction claims. International Construction Law Review, 15(1): 144-160.

Lee, C., Won, J.W., Jang, W., Jung, W., Han, S.H. and Kwak, Y.H. (2017). Social conflict management framework for project viability: Case studies from Korean megaprojects. International Journal of Project Management, 35(8): 1683-1696. https://doi.org/10.1016/j.ijproman.2017.07.011.

LTSF (Litigation Trends Survey Findings) (2013). The Ninth Annual Report of the LTSF. Houston, TX: Fulbright and Jaworski L.L.P. Available at: www.fulbright.com.

Majlis (1972). Mâdeye Vâhedeya Lâyeheya Ghânoni Râjeø ba Eslâhe Tabsarehe 80 Ghânoneh Bodjeh [Single article of the Bill on Amendments to Note 80 of the Budget Act]. Tehran: Majlis Shorâyeh Islami.

Maskin, E.S. (2008). Mechanism design: How to implement social goals. American Economic Review, 98(3): 567-576. https://doi.org/10.1257/aer.98.3.567.

Mayring, P. (2014). Qualitative content analysis: Theoretical foundation, basic procedures and software solution. In A. Bikner-Ahsbahs, C. Knipping and N. Presmeg (eds.), Approaches to Qualitative Research in Mathematics Education. Dordrecht, Netherlands: Springer, 365-380. https://doi.org/10 .1007/978-94-017-9181-6_13.

McGaw, M.C. (1995). Adjudicators, experts and keeping out of court. Construction Law Journal, 8(4): 332-359.

Menassa, C.C. (2009). Quantitative Framework to Evaluate Alternative Dispute Resolution Investments in Architecture Engineering and Construction Projects Using Option and Real Option Theory. Ann Arbor, Ml: ProQuest LLC.

Mohamed, $O$. (2014). Knowledge sharing initiatives in local authorities in Malaysia. PhD diss. University of Salford.

Mohd Danuri, M.S., Ishan, Z.M., Mustaffa, N.E., Karim, S.B.A., Mohamed, O. and Hanid, M. (2016). Dispute avoidance procedure: Formulating a workable legal system in the Malaysian construction industry. Journal of Design and Built Environment, 16(1): 37-46. https://doi.org/10.22452/jdbe.vol16nol.4.

Mohd Danuri, M.S., Mohd Ishan, Z., Mustaffa, N.E., Abd-Karim, S.B., Mohamed, O. and A-Rahmin, R.A. (2015). Dispute avoidance procedure: observing the influence of legal culture towards a workable legal system. Pertanika Journal of Social Sciences and Humanities, 23(2): 509-535.

MPO (Management and Planning Organization) (2006). Nezâmeh Fani v Egrâye Kashvar [Country technical and executive system], Circular No 1-42339//T 3497, July. Tehran: MPO. Available at: http://tec.mporg.ir/Portal/View/Page. aspx?Pageld=24cddfab-d2f8-4ff9-a473-2176d7a24686.

Ndekugri, I. and Russell, V. (2005). Insolvency and resolution of construction contract disputes by adjudication in the UK construction industry. Construction Management and Economics, 23(4): 399-408. https://doi.org/10.1080/01446 19042000326747.

Nelson, S. (2003). Advanced legal concepts. CE 395U.3 class notes. University of Texas at Austin. 
Omoto, T., Kobayashi, K. and Onishi, M. (2002). Bargaining model of construction dispute resolution. In IEEE International Conference on Systems, Man and Cybernetics. Vol. 7. Reston, VA: Institute of Electrical and Electronics Engineers (IEEE). https://doi.org/10.1109/icsmc.2002.1175658.

Peña-Mora, F. and Tamaki, T. (2001). Effect of delivery systems on collaborative negotiations for large-scale infrastructure projects. Journal of Management in Engineering, 17(2): 105-121. https://doi.org/10.1061/(asce)0742-597x(2001) 17:2(105).

Pena-Mora, F., Sosa, C.E. and McCone, D.S. (2003). Introduction to Construction Dispute Resolution. Upper Saddle River, NJ: Prentice Hall.

President Deputy in Strategic Planning and Control (2015). Mørefie mâvenate: Vazayef; Tehran [Introducing deputy: Duties; Tehran]. Available at: http://old. spac.ir/Portal/Home/ShowPage.aspx.

Ranjbar, A. (2003). Shyve Hay Hale Ekhtelafate Jayghzin dr Hghoghe Dakhle [Alternative dispute resolution methods in internal law]. Tehran: Islamic Parliament Research Center of the Islamic Republic of Iran.

Ross, D. (n.d.). Construction disputes resolution. Available at: http://www.layngross. com.

Saeb, A. (2019). Enhancement of dispute resolution mechanism in the Iranian construction industry. PhD diss. University of Malaya.

. (2012). Price list method diagnosis and propose an initiative. Master's diss. University of Shahid Beheshti.

Saeb, A., Mohamed, O.B., Danuri, M.S.B.M. and Zakaria, N.B. (2018a). Critical factors for selecting a neutral to support alternative dispute resolution methods in the construction industry. Civil Engineering Journal, 4(1): 11-23. https://doi. org/10.28991/cej-030965.

(2018b). Development of alternative dispute resolution in the Iranian construction industry. Malaysian Construction Research Journal (MCRJ), 3(1): 25-36.

Saeb, A., Mohd Danuri, M.S.B., Zakaria, N.B. and Mohamed, O.B. (2020). A case study of dispute resolution methods pertaining to the construction standard form in Iran. International Journal of Construction Education and Research, 16(3): 211-230. https://doi.org/10.1080/15578771.2019.1575937.

Sandholm, T. (2003). Automated mechanism design: A new application area for search algorithms. In F. Rossi (ed.), Principles and Practice of Constraint Programming: CP 2003. Berlin, Heidelberg: Springer, 19-36. https://doi. org/10.1007/978-3-540-45193-8_2.

Saunders, M.N., Saunders, M., Lewis, P. and Thornhill, A. (2011). Research Methods for Business Students. 5th Ed. New Delhi: Pearson Education India.

Shadbolt, R.A. (1999). Resolution of construction disputes by disputes review boards. International Construction Law Review, 16: 101-111.

Shin, K.C.K. (2000). Identification of critical dispute characteristics (CDCs) during construction project operations. PhD diss. Georgia Institute of Technology.

Sourdin, T.M. (2006). Legislating for Alternative Dispute Resolution: A Guide for Government Policy Makers and Legal Drafters. Canberra: National Alternative Dispute Resolution Advisory Council (NADRAC).

Steen, R.H. and MacPherson, R.J. (2000). Resolving construction disputes out of court through ADR. Journal of Property Management, 65(5): 58-58. 
Stipanowich, T.J. (1997). At the cutting edge: Conflict avoidance and resolution in the US construction industry. Construction Management and Economics, 15(6): 505-512. https://doi.org/10.1080/014461997372700.

Stipanowich, T. (1987). Arbitration and the multiparty dispute: The search for workable solutions. lowa Law Review, 72: 473.

Trantina, T.L. (2003). An Attorney's Guide to Alternative Dispute Resolution (ADR): ADR 1.01. Bedminster, NJ: Van Nostrand.

Treacy, T.B. (1995). Use of alternative dispute resolution in the construction industry. Journal of Management in Engineering, 11(1): 58-63. https://doi.org/10 $.1061 /$ (asce)0742-597x(1995)11:1(58).

Winter, G. (2000). A comparative discussion of the notion of "validity" in qualitative and quantitative research. The Qualitative Report, 4(3): 1-14.

World Bank (2011). Settling out of court: Financial and private sector development vice presidency. Note Number 329, 2011, October. Washington DC: World Bank.

Yousefzade, M. (2004). Gozveye hoghoghe kârshenâs [Booklet of expert law]. In Enteshârâte Sâzemâne Nezâm Mohandesi Sâkhtemân [Construction Engineering Organization Publication]. Tehran: Construction Engineering Organization. 